\title{
Improving Indoor Air Quality in Classrooms via Wind-Induced Natural Ventilation
}

\author{
Mohannad Bayoumi \\ Department of Architecture, King Abdulaziz University, Jeddah, Saudi Arabia \\ Correspondence should be addressed to Mohannad Bayoumi; mohannad.bayoumi@gmail.com
}

Received 22 November 2020; Revised 20 April 2021; Accepted 22 May 2021; Published 10 June 2021

Academic Editor: Houari Ameur

Copyright ( 2021 Mohannad Bayoumi. This is an open access article distributed under the Creative Commons Attribution License, which permits unrestricted use, distribution, and reproduction in any medium, provided the original work is properly cited.

\begin{abstract}
Student performance in classrooms is related to the indoor environmental quality. High air change rates are necessary to secure an acceptable level of indoor air quality and provide fresh air, which require large amounts of energy and technical installations. Mostly, mechanically supplied air is partially mixed with the return air. In warm climates, the capacity for natural ventilation is not fully exploited in modern buildings. During periods of acceptable outdoor temperatures, buildings need to adapt and employ available free renewable resources, such as wind. In this context, the building form, orientation, and envelope openings are crucial to enable an increased air change rate, user satisfaction, and energy savings. Owing to the difficulty of providing cross-ventilation in buildings with double-loaded corridors, single-sided ventilation is the most common approach. This study investigates the methods to improve the wind-driven air exchange of classrooms in warm climates, where naturally ventilated corridors help increase air movement. This study examines the potential of a set of alternatives within the context of a generic model regarding the pressure distribution, thermal sensation, air velocity, and air change rate. The study suggests that no single opening scenario can be applied to all façades at any time. Each façade requires special treatment. Decisions on natural ventilation need to be made during the early design stages for each façade. It was found that with the aid of low-tech modifications, remarkable increases in air change rates, in some cases up to 14.5 times that of the typical single-sided ventilation case, could be achieved.
\end{abstract}

\section{Introduction}

Natural ventilation is a practical method for reducing energy consumption in the building sector and improves the wellbeing of occupants by affecting the indoor air quality (IAQ). Nonetheless, elevated air velocity is an effective method for improving thermal sensation in hot humid climates under certain conditions [1-3]. Practical experience with the development of such historical solutions to suit contemporary buildings has shown great potential for providing excellent indoor thermal conditions and IAQ, with less use of building systems and energy consumption [4-9].

Educational facilities are among the highest contributors to the increased energy consumption of cities. In fact, university campuses are often regarded as small cities [8]. In particular, a classroom space is a challenging entity because, compared with an office room, a relatively large number of occupants use the space while performing mental and physi- cal activities. Therefore, a considerable amount of fresh air is required to maintain an acceptable reduction in $\mathrm{CO}_{2}$ concentrations, among other volatile organic compounds. Moreover, increased levels of $\mathrm{CO}_{2}$ can lead to drowsiness, eye irritation, and an inability to concentrate. Furthermore, a study related to school attendance and educational attainment in Scotland found that insufficient fresh air supply in classrooms, which is indicated by $\mathrm{CO}_{2}$ levels beyond $1,000 \mathrm{ppm}$, may be associated with reduced school attendance [10].

Classroom buildings in hot climates are commonly cooled and ventilated using the all-air method, where large volumes of air are circulated through the indoor environment to extract the cooling loads via convective heat transfer. An investigation within the framework of classrooms in Kuwait asserts that in such hot climates, typical cooling and ventilation approaches, where fresh air is not introduced into the classroom, result in high $\mathrm{CO}_{2}$ concentrations, reaching 
$1,596 \mathrm{ppm}$, which is far beyond the maximum limit of $1,000 \mathrm{ppm}$ [11]. Especially during times of acceptable outdoor air temperatures, it is sensible to consider natural or even hybrid ventilation (mechanical and natural) supported by radiant cooling. The latter is practical under certain conditions because of the significantly higher thermal capacity of water compared with air, which increases the efficiency of the heat extraction process from the room substantially [12-15].

\subsection{Impact of Natural Ventilation on Indoor Air Quality and} Energy Saving. In Europe, $40 \%$ of building energy consumption is reserved for mechanical ventilation, which also causes $35 \%$ of the $\mathrm{CO}_{2}$ emissions [16].

Insufficient fresh air availability in indoor spaces leads to the accumulation of pollutants and an increase in $\mathrm{CO}_{2}$ concentrations, which eventually leads to sick building syndrome [17]. Outdoor fresh air can be provided using window ventilation, either by wind flow or buoyancy. Especially in hot humid climates, cross-ventilation is effective because it helps increase the air exchange in the room and, above all, introduce fresh air into the space continuously.

Natural ventilation can be either wind-driven or buoyancy-driven. Several studies have asserted that winddriven ventilation is more effective in tropical environments because of the small temperature difference between indoor and outdoor spaces [18-20].

A naturally ventilated room can be configured to utilize single-side or cross-ventilation techniques. The first indicates a room with a window or openings on only one side. In crossventilation, outdoor air enters the building through and inlet on the positive pressure side (e.g., window) and exits through an outlet on the negative pressure side, which can be a window or a roof vent in most cases. Simply, with open windows on both sides of the room, overpressure on the side of the building facing the wind and a lower pressure on the opposite, sheltered side, will create a current of air through the room.

Several studies have demonstrated that architectural building components significantly impact the performance of wind-driven ventilation [21-25]. Among other features, the location and size of the inlets and outlets, as well as the building form, significantly affect the pressure differentials over the building skin. The pressure difference $(\Delta P)$ across each opening or at any point on the building surface is an essential aerodynamic parameter and is usually expressed in the form of a pressure coefficient $(C p)$, which is a function of $\Delta P$ and dynamic pressure $\left(P_{d}\right)$ :

$$
\begin{gathered}
C p=\frac{\text { Pressure difference }}{\text { Dynamic pressure }}=\frac{\Delta P}{P_{d}}, \\
C p=\frac{P_{s}-P_{0}}{1 / 2 \rho U_{\mathrm{ref}}^{2}},
\end{gathered}
$$

where $U_{\text {ref }}$ and $P_{0}$ are the free-stream wind speed and the pressure at a reference height, respectively. $P_{s}$ is the static pressure on the building surface or window opening. The pressure coefficient $(C p)$ values across the openings are essential for determining the airflow volume per unit time.
Their distribution over the building envelope is directly affected by the wind velocity, direction, opening geometry, building form, and height.

1.2. Single-Sided and Cross-Ventilation Potentials and Challenges. Allocca et al. [26] investigated and analyzed a number of solutions within the context of single-sided ventilation, validated the analytical, empirical, and computational fluid dynamics (CFD) models, and revealed and discussed the trends. Among the various results of this study, CFD was found to be useful and practical for the analysis process to understand the complexities and characteristics of such ventilation approaches.

Hybrid ventilation, where natural ventilation is supported by mechanical ventilation when needed, has proven to improve air quality $[27,28]$ and thermal comfort $[27,29]$. Furthermore, hybrid ventilation reduces cooling loads when cooling indoor spaces $[29,30]$.

Studies such as those by Aflaki et al. [31], Arinami et al. [32], and Wang and Chen [33] explored methods to extend the potentials of single-sided ventilation and overcome its limitations. Using a transom ventilation panel in high-rise buildings transforms single-sided ventilation into crossventilation. In a study by Aflaki et al. [31], the air velocity was doubled by 2.4 .

However, within the scope of natural ventilation, crossventilation achieved the best performance in a study by $\mathrm{Ma}$ et al. [34] that examined and compared the kinematics of the flow in several room and ventilation configurations. Interestingly, it was found that the leeward opening provides a better situation for single-sided ventilation. Despite the differences in the rotation direction of the vortices generated inside the building, the large vortex behind the building causes an increase in air velocity in the leeward ventilation. The decrease in air change rate in windward conditions has also been confirmed by Wang et al. [35]. It was found that wind and buoyancy forces can counteract the forces in some situations. Thus, these observations suggest the importance of investigating rooms on different sides of a building at various indoor and outdoor temperatures.

The effectiveness of cross-ventilation in reducing $\mathrm{CO}_{2}$ concentrations was further confirmed in a study that investigated several window control patterns, decreasing the concentrations by up to $82 \%$ during a 20 -minute break [36].

Natural ventilation in conventional classrooms is commonly limited to single-sided window openings despite the lower efficiency, because it is difficult to practically provide every room with double-sided window ventilation. The other sides are often surrounded by neighboring rooms and corridors. Furthermore, fire codes and privacy requirements make cross-ventilation less favored by designers [26]. To date, several studies have investigated methods to enhance single-sided natural ventilation in different building types [17, 37-39].

Figure 1 presents two general conditions of pressure distribution along the surface of a rectangular building in two wind directions. While positive pressure was exerted on the windward side in both cases, negative pressure was generated on the other sides. Obviously, the magnitude of the 


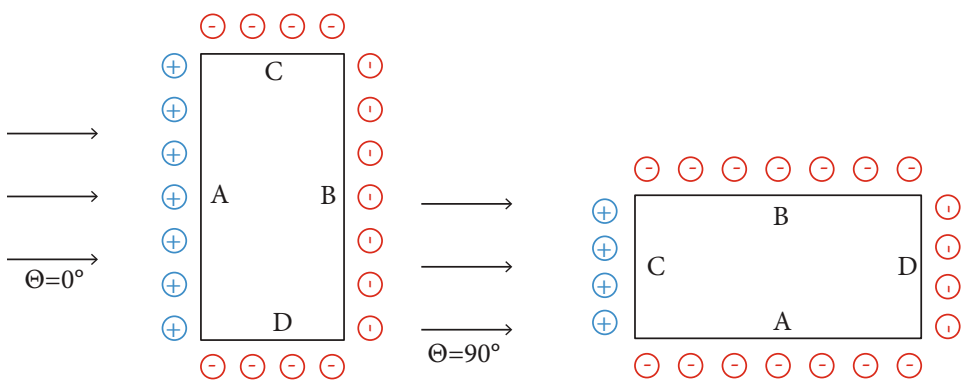

(a)

(b)

FIGURE 1: Simplified illustration of the pressure distribution over the surface of a rectangular building by different wind directions.

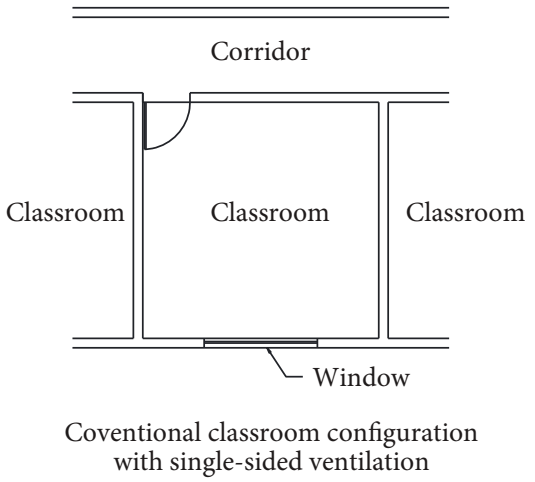

(a)

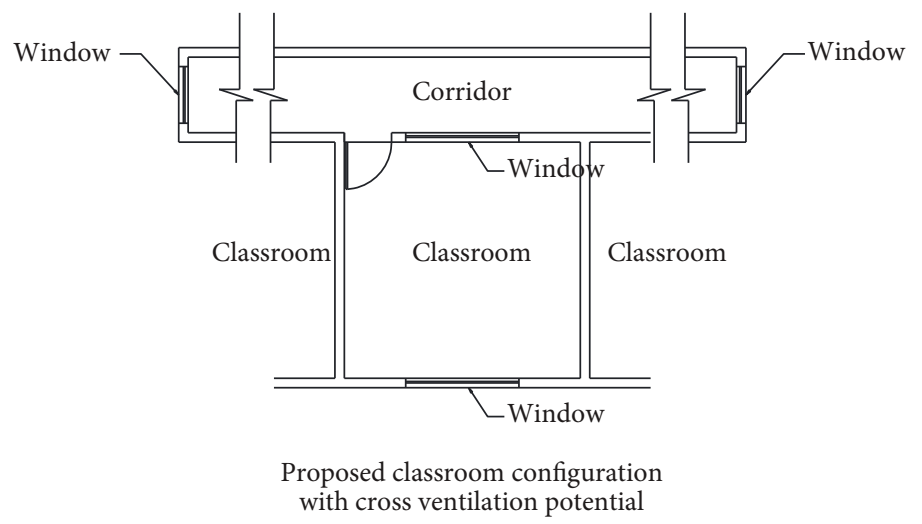

(b)

Figure 2: (a) Conventional single-sided ventilation configuration. (b) Proposed cross-ventilation approach.

pressure levels is not uniform and depends on many factors. In the left image, the pressure drop between façades A and B provides the simplest form of cross-ventilation if a room connects both sides uninterruptedly.

In the case of the conventional single-sided ventilation approach, the pressure differential along the façade has nearly no effect on the natural ventilation condition.

Most studies in this field have only focused on the singlesided window opening without considering the potential of openings located in adjacent spaces that are exposed to side façades $C$ and $D$. These façades can make use of the pressure resulting in differentials along the building envelope to support wind-induced natural ventilation.

This study demonstrates a method to transform a singlesided ventilation condition (Figure 2(a)) into a crossventilation condition using corridor openings (Figure 2(b)). This approach requires integration with the building envelope as well as the building form because of their effect on the pressure distribution over the building surface. After simulating a set of opening configurations for two wind directions, the resulting local values of comfort, air velocity, and air quality were analyzed, and a set of optimum criteria was determined.

\section{Method}

2.1. CFD Simulation Setup, Computational Domain, and Boundary Conditions. The 3D steady Reynolds-averaged
Navier-Stokes (RANS) equations were used to simulate the airflow around and inside the building model. The RANS equations can be derived by substituting the mean and fluctuating components of the airflow variables into the Navier-Stokes equations. The air is incompressible, which is reasonable for the atmospheric boundary layer (ABL) flows [40]. The flow fields were simulated using a 3D CFD analysis based on the standard $k-\varepsilon$ model [41], which is widely used in engineering applications. The continuity equation and the fundamental equations governing the motion of steady, incompressible, and turbulent flows are the averaged Navier-Stokes equations, which can be expressed as follows:

Continuity equation:

$$
\frac{\partial \rho}{\partial t}+\frac{\partial}{\partial x_{j}}\left(\rho U_{i}\right)=0
$$

Momentum conservation equation:

$$
\frac{\partial \rho U_{i}}{\partial t}+\frac{\partial}{\partial x_{j}}\left(\rho U_{i} U_{j}\right)=-\frac{\partial p^{\prime}}{\partial x_{i}}+\frac{\partial}{\partial x_{j}}\left[\mu_{\text {eff }}\left(\frac{\partial U_{i}}{\partial x_{j}}+\frac{\partial U_{i}}{\partial x_{i}}\right)\right]+S_{M}
$$

where $S_{M}$ represents the sum of the body forces, $\mu_{\text {eff }}$ is the effective viscosity that indicates the turbulence, and $p^{\prime}$ represents the modified pressure. Therefore, the left side of Equation (4) represents convection, and the right side is 


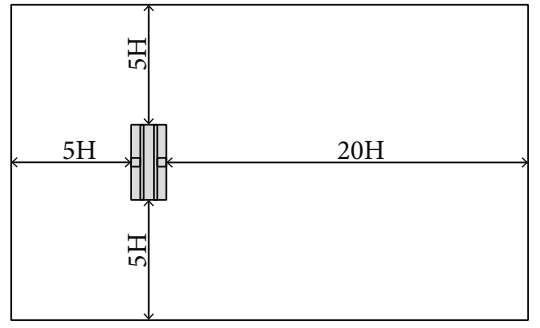

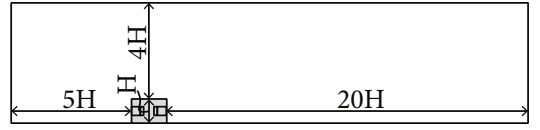

(a)

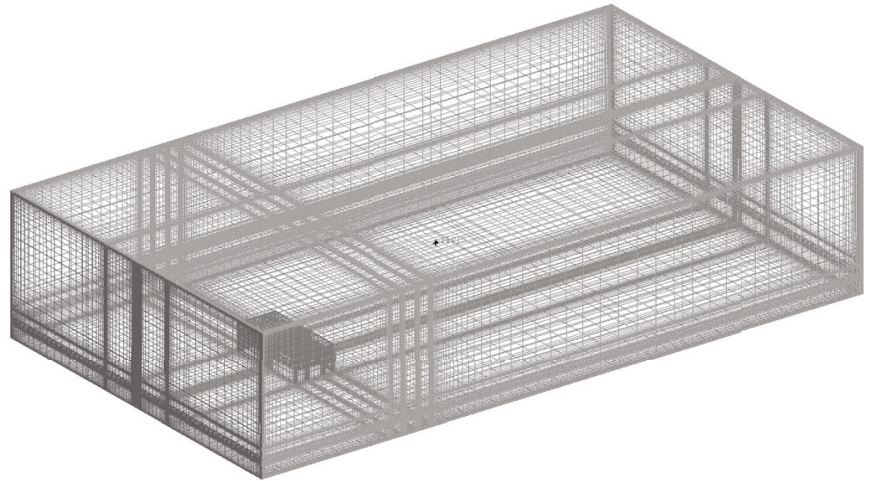

(b)

Figure 3: (a) Applied spacings in domain modeling. (b) Example of the simulation mesh used.

related to pressure, body forces, diffusion, and the momentum interaction between forces, respectively.

According to detailed experimental verification studies by Catalina et al. [42] and Feustel and Stetiu [13], the standard $k-\varepsilon$ model can be used for practical investigations in relation to indoor and outdoor flows.

To explain the effect of turbulence, $\mu_{\text {eff }}$ is replaced with $\mu_{t}$ in Equation (5), which is the turbulence viscosity and is modeled in Equation (6). The values of $k$ and $\varepsilon$ are calculated from the transport equations that describe the kinetic energy and turbulence dissipation rate, Equations (7) and (8), respectively. $P_{k}$ in Equation (9) depicts the turbulence production owing to the viscous forces.

$$
\begin{gathered}
\mu_{e f f}=\mu+\mu_{t}, \\
\mu_{t}=C_{\mu} \rho \frac{k^{2}}{\varepsilon}, \\
\frac{\partial(\rho k)}{\partial t}+\frac{\partial}{\partial x_{j}}\left(\rho U_{j} k\right)=\frac{\partial}{\partial x_{j}}\left[\left(\mu+\frac{\mu_{t}}{\sigma_{k}}\right) \frac{\partial k}{\partial x_{j}}\right]+P_{k}-\rho \varepsilon+P_{k b}, \\
\frac{\partial(\rho \varepsilon)}{\partial t}+\frac{\partial}{\partial x_{j}}\left(\rho U_{j} \varepsilon\right)=\frac{\partial}{\partial x_{j}}\left[\left(\mu+\frac{\mu_{t}}{\sigma_{\varepsilon}}\right) \frac{\partial \varepsilon}{\partial x_{j}}\right] \\
+\frac{\varepsilon}{k}\left(C_{\varepsilon 1} P_{k}-C_{\varepsilon 2} \rho \varepsilon+C_{\varepsilon 1} P_{\varepsilon b}\right), \\
\left(\frac{\partial U_{i}}{\partial x_{j}}+\frac{\partial U_{j}}{\partial x_{i}}\right) \frac{\partial U_{j}}{\partial x_{j}}-\frac{2}{3} \frac{\partial U_{k}}{\partial x_{k}}\left(3 \mu_{t} \frac{\partial U_{k}}{\partial x_{k}}+\rho k\right),
\end{gathered}
$$

where $1.44,1.92,0.09,1.0$, and 1.3 are set as the constants $C_{\varepsilon 1}, C_{\varepsilon 2}, C_{\mu}, \sigma_{k}$, and $\sigma_{\varepsilon}$, respectively.

As shown in Figure 3, a rectangular domain was created for the CFD simulations. The parameters of the model were created in accordance with the best practice guidelines for the CFD simulation [43] and AIJ ([44], and [45, 46]). The domain width, length, and height were $462 \mathrm{~m}, 262 \mathrm{~m}$, and $100 \mathrm{~m}$, respectively. Moreover, the mesh was constructed using ICEM CFD, which allowed the creation of a hexahedral mesh around and inside the building model.

The solid walls were considered aerodynamically smooth and assigned a no-slip boundary condition property. The symmetric wall boundary condition 1 was also applied to the lateral and top boundaries. The outlet plane was assigned a static pressure of zero.

Considering the $\mathrm{ABL}$ is critical because the wind speed increases with height [47]. Different methods were used to model the ABL. It is common in the fields of wind engineering to use the power law that was suggested by Hellmann [48], which is considered reliable [49]. The power law is expressed in Equation (10) and is used according to Peterson and Hennessey [50]. The wind velocity is represented by $U_{\star}$. In addition, $U_{H}$ represents the wind velocity at a $10 \mathrm{~m}$ height. The variable $\approx$ represents the changing heights. The reference height is $10 \mathrm{~m}$ and is represented as $H . \alpha$ is related to the surface roughness factor of the site and was set to 0.25 [51], which describes suburban conditions [52].

The velocity at the inlet and the turbulent kinetic energy (TKE) profiles were adapted from the experimental work of Tominaga and Blocken [53]. Both are illustrated in Figure 4 which presents the conditions of the lower part of the boundary layer.

$$
\frac{U_{\text {え }}}{U_{\text {ref }}}=\left(\frac{\varkappa}{H}\right)^{0.25} \text {, }
$$

where $U_{\text {ref }}=4.3(\mathrm{~m} / \mathrm{s})$ is the reference velocity at building height $H$. The TKE profile was measured and approximated by the exponential formulation provided by [53]. The dissipation rate $\varepsilon_{\text {竞 }}$ of the TKE was calculated in accordance with the guidelines of the AIJ [44].

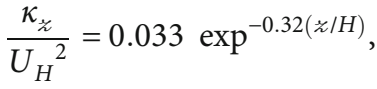

$$
\begin{aligned}
& \varepsilon_{\text {え }}=C_{\mu} \frac{1}{2} \kappa_{z} \frac{U_{H}}{H} \alpha\left(\frac{\text { ๘ }}{H}\right)^{\alpha-1} \text {, }
\end{aligned}
$$

where $C_{\mu}=0.09$ indicates the model constant and $\alpha=0.25$. 

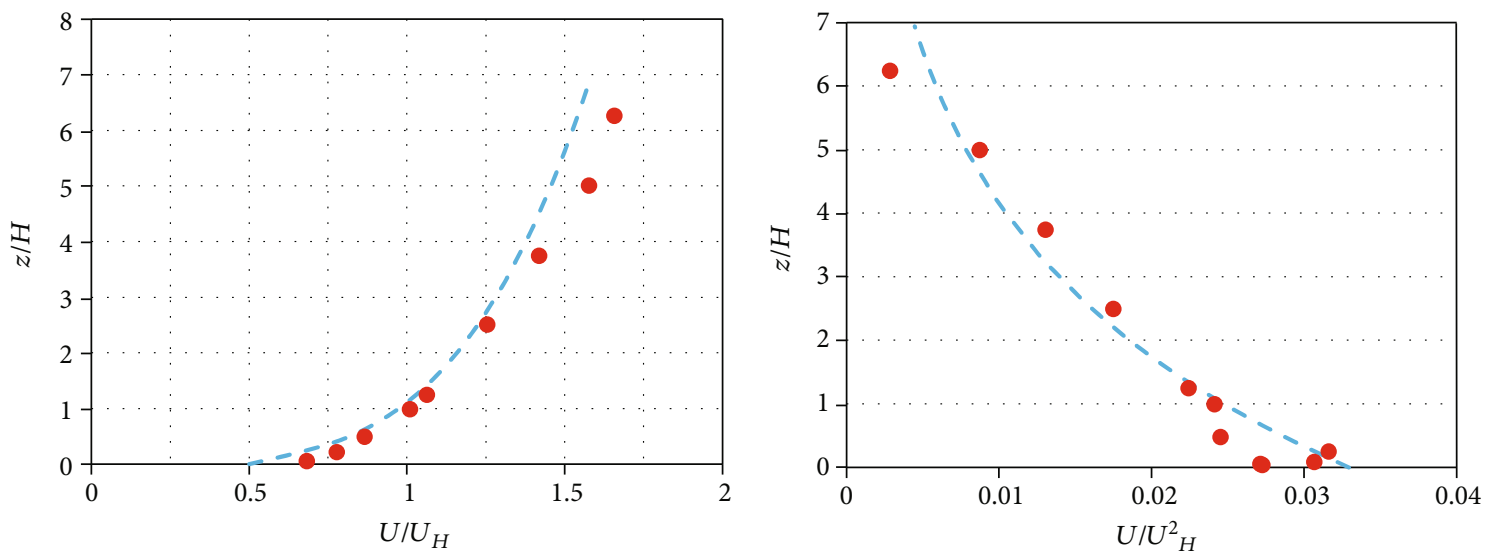

- Inlet flow

- Experiment

(a)

(b)

Figure 4: (a) Inlet vertical wind profile. (b) Turbulent kinetic energy.
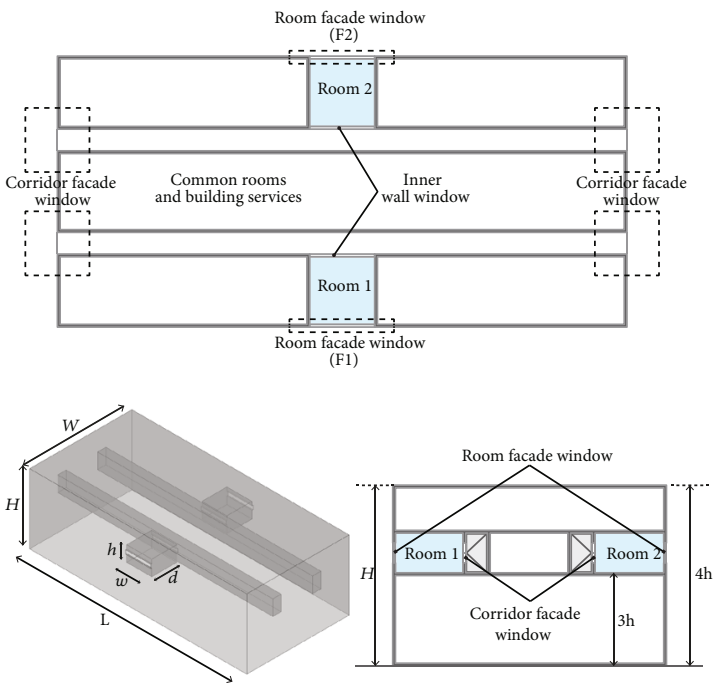

(a)
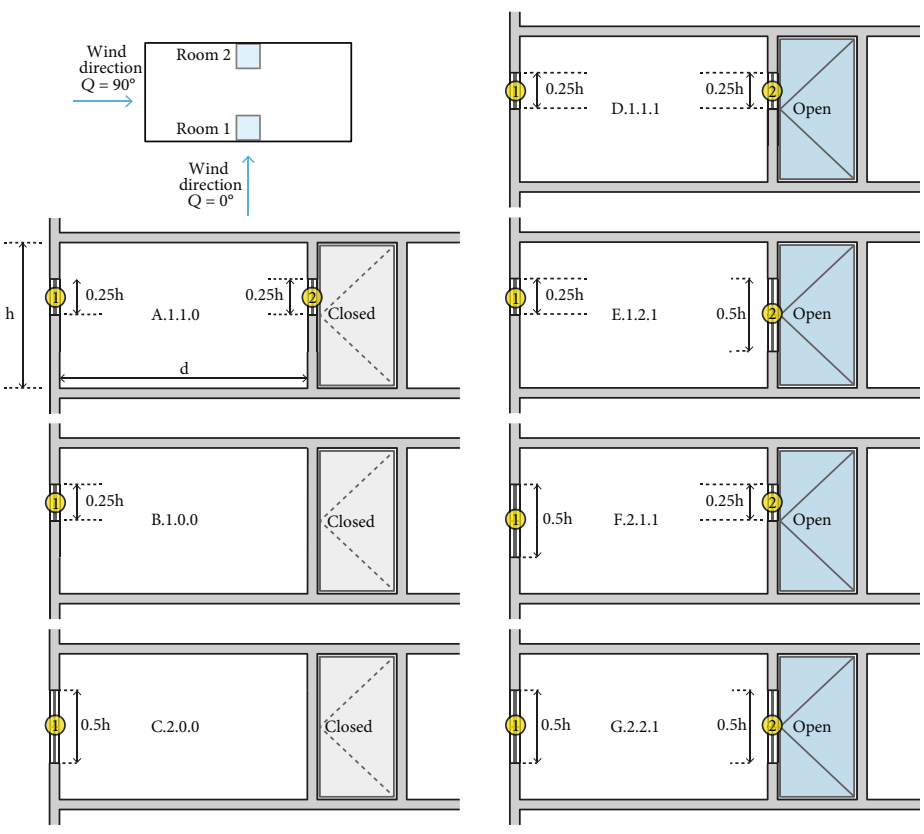

(b)

FIGURE 5: (a) Configuration of building model. (b) Illustration of simulation cases.

2.2. Building Model. The analysis model used in this investigation consisted of a modular classroom space in a rectangular building, with the room dimensions of $7.2 \times 7.2 \times 4.0 \mathrm{~m}$ and building dimensions of $60.0 \times 30.0 \times 20.0 \mathrm{~m}$ for the length, width, and height, respectively. The classroom model was incorporated on both sides of the building. The rooms were located on the third floor of a four-story building. Figure 5 illustrates the basic characteristics of the building model as well as the different simulation cases.

The two simulated wind directions, $\Theta=0^{\circ}$ and $\Theta=90^{\circ}$, are shown in Figure 5. When $\Theta=0^{\circ}$, Room 1 is windward and Room 2 is leeward, and when $\Theta=90^{\circ}$, both rooms are considered leeward, and the corridor façade openings on the shorter side of the building are windward.

The data in Table 1 explain the configuration of each simulation case, as illustrated in Figure 5. The widths of all the windows in the outer and inner walls are equivalent to the width of the room. In addition, the opening size of the corridor façade was $100 \%$, which means that the window had the same width and height of the corridor. The name of each case consists of a letter and three digits. The first digit indicates the window fraction of the exterior façade of the room. Therefore, if the number is 1 , the height of the window is $0.25 \mathrm{~h}$ which is $1 \mathrm{~m}$. If the number is 2 , the height is $0.5 \mathrm{~h}$, 
TABLE 1: Description of simulation cases.

\begin{tabular}{|c|c|c|c|c|c|c|}
\hline & \multicolumn{2}{|c|}{$\begin{array}{l}\text { Façade } \\
\text { Window } \\
\text { fraction }\end{array}$} & \multicolumn{2}{|c|}{$\begin{array}{l}\text { Corridor wall } \\
\text { Window } \\
\text { fraction }\end{array}$} & \multicolumn{2}{|c|}{$\begin{array}{c}\text { Corridor façades } \\
\text { Windows }\end{array}$} \\
\hline & $25 \%$ & $50 \%$ & $25 \%$ & $50 \%$ & Closed & Open \\
\hline A.1.1.0 & 口 & & 口 & & 口 & \\
\hline B.1.0.0 & 口 & & & & 口 & \\
\hline C.2.0.0 & & 口 & & & 口 & \\
\hline D.1.1.1 & 口 & & 口 & & & घ \\
\hline E.1.2.1 & 口 & & & 口 & & 口 \\
\hline F.2.1.1 & & 口 & 口 & & & 口 \\
\hline G.2.2.1 & & [ & & [ & & च \\
\hline
\end{tabular}

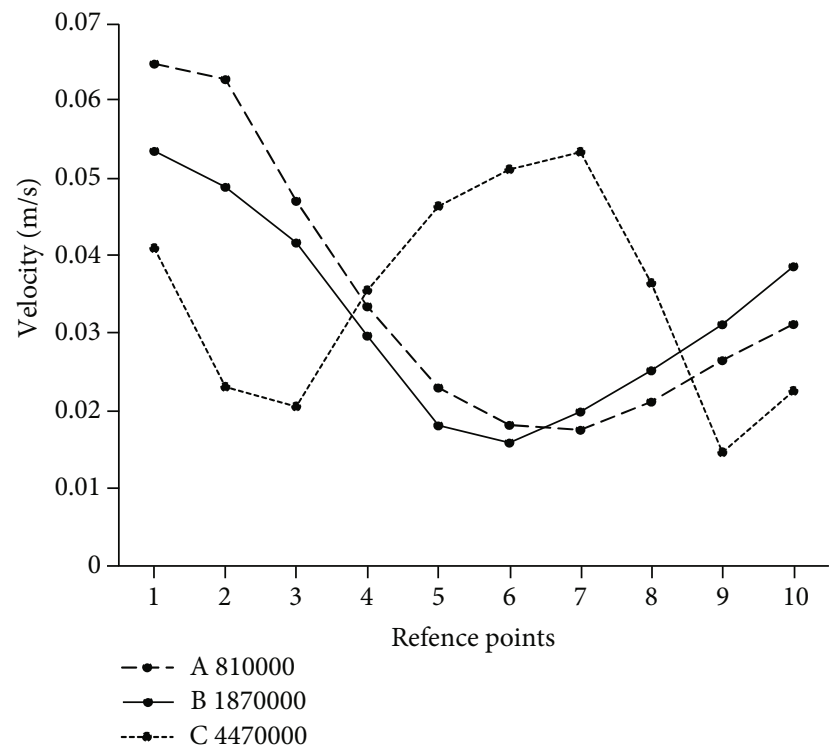

FIGURE 6: Grid independence analysis.

which is $2 \mathrm{~m}$. The same rules apply to the second digit, which is related to the inner wall. The third digit is a binary 0 or 1 digit that indicates whether the corridor windows are open or closed, with 0 meaning open and 1 meaning closed.

2.3. Grid Sensitivity Analysis. To assess the sensitivity of the grid for the simulation and to find an independent mesh from the cell sizes, a sensitivity analysis was conducted, and the velocity was calculated at reference points in the three grid cases: Grid-A, 810,000 cells; Grid-B, 1,187,000 cells; and Grid-C, 4,470,000 cells. The interval between each grid case increases by approximately 2.3 times. Practical methods for the grid sensitivity analysis can be reviewed in the following literature: Catalina et al. [42] and Ramponi et al. [54]. The reference points for the velocity values were simulated in a cavity that represented the model room (point height: in the room $=2.5 \mathrm{~m}$, in the domain $=12.5 \mathrm{~m}$ ).

From Figure 6, the standard deviation in the wind velocity between the results of the fine Grid-C and medium Grid-B is not remarkable at less than 0.02 . Therefore, the rest of the simulations were conducted using Grid-B to reduce the time required for the simulations.

\subsection{Comfort Models}

2.4.1. Thermal Comfort. Although comfort can currently be met with the aid of air conditioning systems, a synergy exists with passive and active solutions, such as cross-ventilation and radiant cooling. The latter is out of the scope of this study, because using a radiant cooling system, for example, a chilled ceiling, in a hot humid climate can be challenging owing to the risk of condensation. Studies by Bayoumi [55], Feng et al. [56], Hirayama and Batty [57], and Nutprasert and Chaiwiwatworakul [58] present methods to overcome this problem. Thermal comfort is affected by several objective and subjective physical parameters. Increasing air velocity is a key measure that, under certain conditions, can remarkably improve human thermal comfort [1, 59-67].

Fanger's thermal comfort model is a useful method for calculating PMV using the following equation [68]:

$$
P M V=\left(0.303^{e-0.036 M}+0.028\right) L,
$$

where $M$ is the metabolic rate and $L$ is the thermal load, which is defined as the difference between the internal heat production and heat loss to the actual environment for a person at a comfortable skin temperature and evaporative heat loss by sweating at the actual activity level. The following is a more detailed description of $L$.

$$
\begin{aligned}
& \left\{(M-W)-3.96 E^{-8} f_{c l}\left[\left(t_{c l}+273\right)^{4}-\left(\left(t_{r}+273\right)^{4}\right)\right]\right. \\
& \quad-f_{c l} h_{c}\left(t_{c l}+t_{a}\right)-3.05\left[5.73-0.007(M-W)-p_{a}\right] \\
& \quad-0.42[(M-W)-58.15]-0.0173 M\left(5.87-p_{a}\right) \\
& \left.\quad-0.0014 M\left(34-t_{a}\right)\right\}
\end{aligned}
$$

From Equation (13), the most important coefficient for heat transfer and the most relevant to this analysis is the heat transfer coefficient for convection $\left(h_{c}\right)$, which is given by the following relation:

$$
h_{c}=12.1 \sqrt{v}\left(\mathrm{~W} / \mathrm{m}^{2} \cdot \mathrm{K}\right)
$$

The importance of this factor within the scope of this study is its direct dependence on air velocity, which is affected by the ventilation method. To eliminate the variations in this analysis, the values of the other coefficients are fixed as follows:

Metabolic rate $=81.0\left(\mathrm{~W} / \mathrm{m}^{2}\right)$, which represents the heat dissipation by the occupants; clothing thermal resistance $\left(R_{\mathrm{cl}}\right)=0.116\left(\mathrm{~m}^{2} \mathrm{~K} / \mathrm{W}\right)$; water vapor partial pressure $\left(P_{\text {Water }}\right)$ $=2,180(\mathrm{~Pa})$, calculated from the given boundary conditions of $\mathrm{Ta}=25^{\circ} \mathrm{C}, \mathrm{RH}=60 \%$; clothing factor $\left(f_{c l}\right)=4$ (light summer clothing); the mean radiant temperature $\left(t_{r}\right)$ was calculated internally in the CFD software and varies according to the surface temperature of the surrounding objects that vary due to radiant cooling in some cases. The PMV index predicts the mean response of a large group of people according to the ASHRAE thermal sensation scale and can be seen in Table 2 . 
TABLE 2: Thermal comfort scale according to ASHRAE.

\begin{tabular}{lcccccc}
\hline+3 & 2 & 1 & 0 & -1 & -2 & -3 \\
Hot & Warm & Slightly warm & Neutral & Slightly cool & Cool & Cold \\
\hline
\end{tabular}

2.5. Indoor Air Quality. The air change rate $(\mathrm{ACH})$ and mean age of air (MAA) are among the practical methods for evaluating the IAQ. With respect to the minimum recommended amount of fresh air supply, the air change rate can be used to determine the sufficiency of supplied fresh air mechanically or naturally. In this study, the CFD model calculates the $C p$ over the building surface and at the openings according to Equation (2). In the theoretical classroom model, the number of occupants was 25 students. According to the recommendations made by Pettenkofer on the minimum fresh air requirements per person [69], an amount of $30 \mathrm{~m}^{3} / \mathrm{h}$ per student should be considered. This accounts for $750 \mathrm{~m}^{3} / \mathrm{h}$ of fresh air. Considering the volume of the classroom model of $207.36 \mathrm{~m}^{3}$, the minimum $\mathrm{ACH}$ is determined from the following equation:

$$
\mathrm{ACH}=\frac{Q}{V}=\frac{750}{207.36}=3.6 \mathrm{~h}^{-1},
$$

where $Q$ is the volume of supplied air per hour $\left(\mathrm{m}^{3} / \mathrm{h}\right)$ and $V$ is the room volume. The procedure used for calculating the supplied air via single-sided and cross-ventilation is according to Swami and Chandra [70], where the Cps and air velocity are the most changing variables. For the cases of single-sided ventilation (B.1.0.0, C.2.0.0), the following equation is used:

$$
Q=0.05 A U_{\text {ref }}(\mathrm{m} / \mathrm{s})
$$

where $A$ is the aperture area of the simulated window, and $U_{\text {ref }}$ is the wind velocity at the building site at the reference height. In this case, the eave height was used as reference eight. To calculate the flow in the cases of cross-ventilation (A.1.1.0, D.1.1.1, E.1.2.1, F.2.1.1, and G.2.2.1) with an inlet and an outlet, the following procedure was used:

$$
Q=C d A U_{\text {ref }} \sqrt{\Delta C p}(\mathrm{~m} / \mathrm{s})
$$

where $C d$ is the discharge coefficient, which was set to 0.62 , according to Swami and Chandra [70], and $\triangle C p$ and $A$ are the pressure coefficient difference across the inlet and outlet and the mean area of the inlet and outlet, respectively.

\section{Results and Discussion}

3.1. Pressure Coefficient Differential $\triangle C p$. The difference in pressure coefficient $\Delta C p$ across the building openings is a decisive factor that affects the amount of air flow as well as its velocity through the building structure. Therefore, an analysis was carried out for each of the seven cases to assess the $\Delta C p$ by subtracting the $C p$ at each opening of both façades (F1, F2) according to Figure 5 for the two wind directions: $0^{\circ}$ and $90^{\circ}$. In cases A.1.1.0, D.1.1.1, E.1.2.1, F.2.1.1, and G.2.2.1, the inner wall adjacent to the corridor has an open-

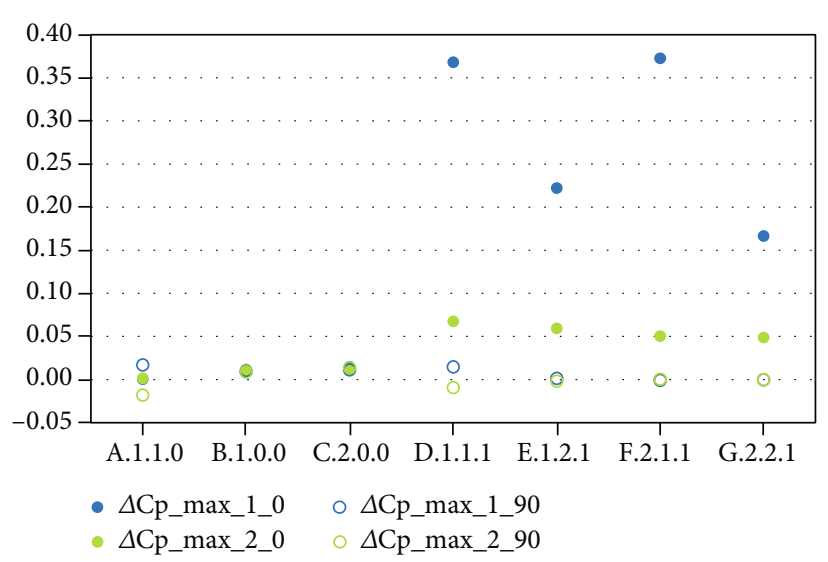

FIgURE 7: Comparison of pressure coefficient difference across simulated cases.

ing to enable cross-ventilation. In each of these cases, a reading point was placed in the middle of both the façade opening and the inner wall opening. The locations of the points are shown in yellow in Figure 5. In the cases with the wind direction $\Theta=0^{\circ}$, Room 1 is windward, and Room 2 is leeward. When $\Theta=90^{\circ}$, Room 1 and Room 2 are on the leeward side.

$$
\Delta C p=\left(C p_{1}^{\text {windward }}-C p_{2}^{\text {leeward }}\right)
$$

The diagram in Figure 7 demonstrates a comparison of the pressure coefficient difference across the simulated cases. In case A.1.1.0, according to Figure 5, there are two window openings of size $25 \mathrm{~h}$ : one is on the outer wall or the façade, and the other is on the inner wall that is adjacent to the corridor. No openings were considered at either end of the corridor. In both rooms when the wind direction angle $\Theta=0^{\circ}$, $\triangle C p$ that is calculated according to Equation (18) is almost 0 , indicating that there is barely any air movement through both façades, F1 and F2, which are associated with Room 1 and Room 2, respectively. However, a slight difference could be noticed when $\Theta=90^{\circ}$, where the values of $\Delta C p$ for Room 1 and Room 2 are 0.02 and -0.02 , respectively. These marginal pressure differentials do not indicate the potential for a substantial movement of air, which may lead to a high air change rate. Therefore, it can be stated that the opening in the inner wall under the given circumstances is not useful for natural ventilation.

Across the five cases shown, no substantial effect on the pressure differential can be seen in the wind direction $\Theta=$ $90^{\circ}$. This is because both rooms are located along the streamline of the wind and thus on the sides of the building.

With the wind direction $\Theta=0^{\circ}$, in case D.1.1.1, where both rooms have $0.25 \mathrm{~h}$ openings in the façade as well as the corridor wall, the windows on both sides of the corridors are open. In the windward Room 1 , a clear increase in $\Delta C p$ can be seen of 0.37 . In Room 2, which is located in the wake zone with a dominant negative pressure, $\triangle C p$ is approximately 0.07 . Increasing the opening size in the corridor wall for both rooms in the case E.1.2.1 to $0.5 \mathrm{~h}$ did not help increase the $\triangle C p$. In fact, a clear reduction is shown for Rooms 1 and 2 to 0.22 and 0.06, respectively. In F.2.1.1, 


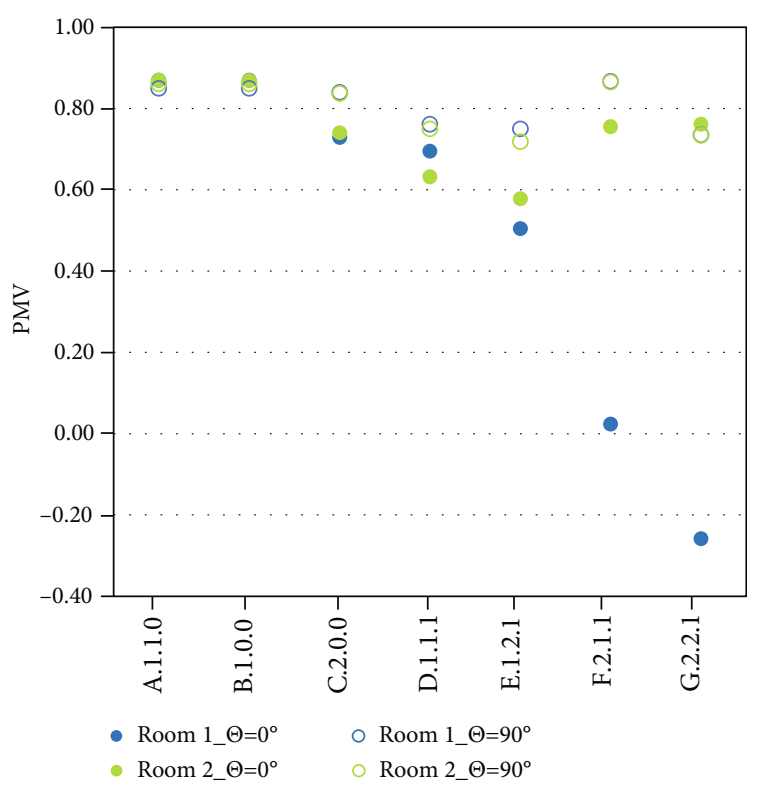

(a)

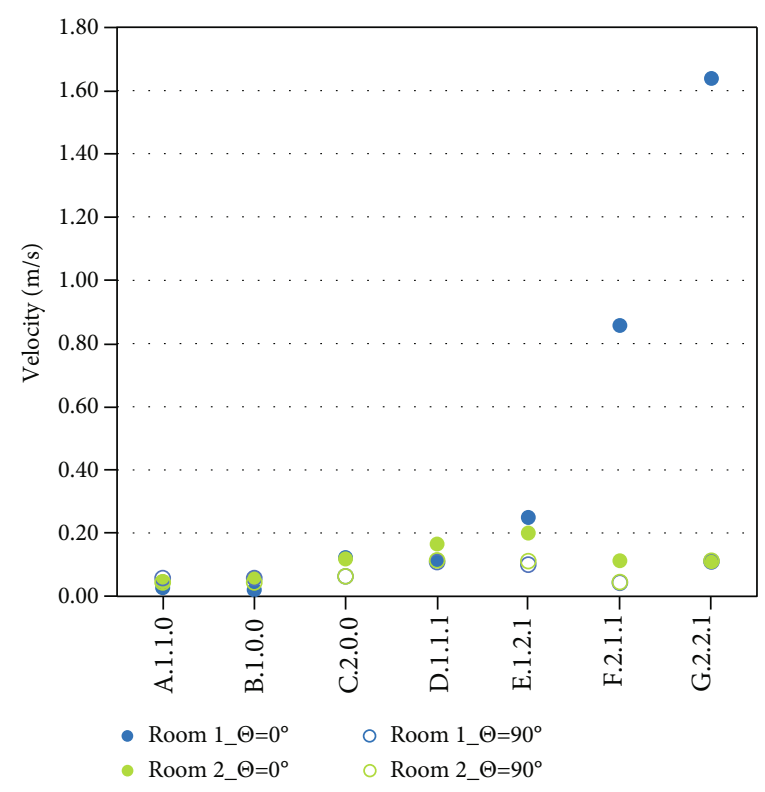

(b)

FIgURE 8: (a) Thermal sensation assessment. (b) Corresponding air velocity to the shown thermal sensation.

which is similar to D.1.1.1, except for the façade opening size that is doubled to reach $0.5 \mathrm{~h}$, the $\Delta C p$ level in the windward Room 1 is similar to D.1.1.1, at 0.37, whereas a slight reduction for Room 2 could be noticed at 0.05 . This result also did not change in the leeward Room 2 of G.2.2.1, while in the windward Room $1, \triangle C p$ was 0.17 .

From the above comparison, it can be established that the opening of corridor windows is essential to improve $\Delta C p$ in the windward and leeward rooms under the given conditions. Also, the openings sizes of $0.25 \mathrm{~h}$ or $0.5 \mathrm{~h}$ essentially affect the $\triangle C p$ in the windward rooms. Yet, the best condition among the five cases was demonstrated in case D.1.1.1, where all the openings for the windward and leeward rooms were $0.25 \mathrm{~h}$. Doubling the opening sizes, such as in F.2.1.1 and G.2.2.1, did not present better conditions for either room or wind direction.

3.2. Thermal Sensation. As the increase in air velocity helps improve thermal sensation under certain conditions, the diagrams in Figure 8 outline the correlation between the resulting wind velocity and thermal sensation. The axis of the left diagram indicates the PMV scale, and the axis of the right diagram shows the related average air velocity in the room. The data shown represent Room 1 and Room 2 under the conditions in two wind directions: $\Theta=0^{\circ}$ and $\Theta=90^{\circ}$. The modeled temperature and relative humidity $\left(28^{\circ} \mathrm{C}, 60 \%\right)$ represent the annual average conditions of the hot humid city of Jeddah, Saudi Arabia. Considering the bioclimatic chart [71], this condition generally lies at the edge of the thermal comfort zone with calm or not moving air around the slightly warm PMV according to Fanger's model. Clearly, an increased air velocity lowers the PMV level and thus improves the thermal sensation.

In the first two cases from Figure 8, for A.1.1.0 and B.1.0.0, no remarkable change could be seen in the thermal sensation, which is approximately 0.86 , as the air velocity is remarkably low in the range $0.00-0.03 \mathrm{~m} / \mathrm{s}$ for $\Theta=0^{\circ}$ and $\Theta$ $=90^{\circ}$, respectively. Even though case C.2.0.0 represents a typical single-sided ventilation case, the slight increase in the velocity with the wind direction $\Theta=0^{\circ}$ to $0.12 \mathrm{~m} / \mathrm{s}$ helped lower the thermal sensation by approximately $13 \%$. This result is primarily attributed to the doubled façade opening size in both rooms. Additionally, in the wind direction $\Theta=$ $90^{\circ}$, no remarkable change could be noticed, and the wind velocity remained at $0.03 \mathrm{~m} / \mathrm{s}$.

Clear changes can be seen in the next four cases because of two factors: openings in the corridor wall and façade openings on both sides of the corridors. In D.1.1.1, for $\Theta=0^{\circ}$, the PMV for Room 1 and Room 2 was lowered to 0.69 and 0.63 , respectively. This also corresponds to an increase in the air velocity up to 0.11 and 0.17 , respectively. Evidently, Room 2 benefited from the negative pressure condition because it was in the wake zone of the building. For $\Theta=90^{\circ}$, the PMV and velocity reached 0.75 and 0.11 , respectively, for both rooms. The thermal sensation improved for E.1.2.1 with $\Theta$ $=0^{\circ}$. Compared with the previous case, the opening in the corridor wall in this case was doubled to $0.5 \mathrm{~h}$. In the windward Room 1, the PMV is approximately 0.50 owing to an air velocity of $0.25 \mathrm{~m} / \mathrm{s}$. In addition, the leeward Room 2 demonstrates a PMV of 0.58 and an air velocity of $0.20 \mathrm{~m} / \mathrm{s}$. Neither the PMV nor the air velocity presented a significant difference when $\Theta=90^{\circ}$.

The best PMV condition (0.02) was reached for Room 1 with $\Theta=0^{\circ}$ in case F.2.1.1, where the façade and corridor wall openings are $0.5 \mathrm{~h}$ and $0.25 \mathrm{~h}$, respectively. However, this approach did not positively affect the conditions of Room 2, where the PMV was 0.76, and the air velocity was $0.11 \mathrm{~m} / \mathrm{s}$. In addition, the PMV in both rooms deteriorated when $\Theta=90^{\circ}$, reaching 0.87 , corresponding to $0.05 \mathrm{~m} / \mathrm{s}$. Another significant reduction in the PMV value could be 
TABLE 3: Best cases with respect to PMV and air velocity.

\begin{tabular}{lccccc}
\hline Room & $(-)$ & 1 & 2 & 1 & 2 \\
\hline Wind direction & $(-)$ & $\Theta=0^{\circ}$ & $\Theta=0^{\circ}$ & $\Theta=90^{\circ}$ & $\Theta=90^{\circ}$ \\
Case & $(-)$ & F.2.1.1 & E.1.2.1 & E.1.2.1 & E.1.2.1 \\
PMV & $(-)$ & 0.02 & 0.58 & 0.72 & 0.72 \\
Velocity & $(\mathrm{m} / \mathrm{s})$ & 0.86 & 0.2 & 0.11 & 0.11 \\
\hline
\end{tabular}

seen in G.2.2.1, where the façade and corridor wall openings are $0.5 \mathrm{~h}$. In the $\Theta=0^{\circ}$ condition, the PMV for Room 1 reached -0.26 and entered the slightly cool zone. The corresponding velocity increased to $1.64 \mathrm{~m} / \mathrm{s}$ which is beyond the recommended maximum of $1.2 \mathrm{~m} / \mathrm{s}$ to avoid blowing papers [72]. The condition for the leeward Room 2 is similar to the previous case and, to a great extent, to those when $\Theta=90^{\circ}$. Table 3 outlines the recommended conditions for each room for each wind direction with respect to the PMV and air velocity. Case E.1.2.1 seems to be the optimum condition for nonwindward cases under the given conditions.

3.3. Air Change Rate. As the air change rate is among the essential factors that indicate the level of hygienic room quality, the simulation results for the various cases are illustrated in Figure 9. The diagram illustrates the conditions for Rooms 1 and 2 in both wind directions $\Theta=0^{\circ}$ and $\Theta=90^{\circ}$. As mentioned previously, there is a need for $750 \mathrm{~m}^{3} / \mathrm{h}$ of fresh air intake to maintain a minimum of $30 \mathrm{~m}^{3} / \mathrm{h}$ per person in the classroom. This accounts for an ACH of almost $3.6 \mathrm{~h}^{-1}$.

In case A.1.1.0, where single-sided ventilation is supported by a $0.25 \mathrm{~h}$ inner wall opening towards the corridor, an extremely low ACH of less than $1 \mathrm{~h}^{-1}$ can be noticed for $\Theta=0^{\circ}$. In the condition of $\Theta=90^{\circ}$, while an increase in the $\mathrm{ACH}$ by nearly $1.0 \mathrm{~h}^{-1}$ is demonstrated, the values remain considerably low with respect to the recommended amount. No significant difference is seen for B.1.0.0, where the typical single-sided ventilation of the $0.25 \mathrm{~h}$ façade opening is considered. For $\Theta=0^{\circ}$, the highest $\mathrm{ACH}$ of $2.1 \mathrm{~h}^{-1}$ is for the windward Room 1, followed by $1.7 \mathrm{~h}^{-1}$. Extremely calm conditions are present for both rooms in the same case with $\Theta$ $=90^{\circ}$. After increasing the opening area to $0.5 \mathrm{~h}$ in the similar case C.2.0.0, the ACH reached 4.2 in Room 1 for $\Theta=0^{\circ}$ and Room 1 and Room 2 for $\Theta=90^{\circ}$. The leeward Room 2 with $\Theta=0^{\circ}$ is comparably low at 2.3. However, these results indicate the impact of the window area on the ventilation performance in single-sided ventilation. An exception was observed in the leeward Room 2 at $\Theta=0^{\circ}$.

The following four cases demonstrate the results of the cases with activated corridor openings. In D.1.1.1, where the façade and inner wall openings are $0.25 \mathrm{~h}$, a substantial increase in $\mathrm{ACH}$ is notable only with $\Theta=0^{\circ}$; Room 1 reached $18.4 \mathrm{~h}^{-1}$, and Room 2 reached $9.0 \mathrm{~h}^{-1}$. Conversely, there was no significant increase with $\Theta=90^{\circ}$, and the values for both rooms remain below 3.0.

An increase in the opening area of the inner wall improved the condition only in windward Room 1 when $\Theta$ $=0^{\circ}$. The resulting $\mathrm{ACH}$ for Room 1 and Room 2 are $22.4 \mathrm{~h}^{-1}$ and $7.4 \mathrm{~h}^{-1}$, respectively. Further deterioration for both rooms for $\Theta=90^{\circ}$ is seen, not only in this case but also

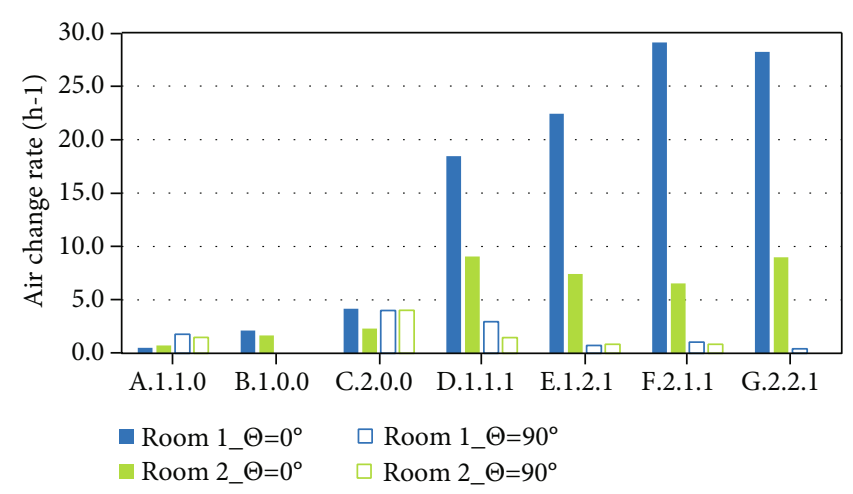

Figure 9: Potential air change rates for the considered cases.

TABle 4: Potential of openings scenarios with respect to the recommended air change rate.

\begin{tabular}{lcccc}
\hline Room & 1 & 2 & 1 & 2 \\
\hline Wind direction & $\Theta=0^{\circ}$ & $\Theta=0^{\circ}$ & $\Theta=90^{\circ}$ & $\Theta=90^{\circ}$ \\
A.1.1.0 & $\square$ & $\square$ & $\square$ & $\square$ \\
B.1.0.0 & $\square$ & $\square$ & $\square$ & $\square$ \\
C.2.0.0 & $\mathbf{\square}$ & $\square$ & $\mathbf{\square}$ & $\square$ \\
D.1.1.1 & $\mathbf{\square}$ & $\mathbf{\square}$ & $\square$ & $\square$ \\
E.1.2.1 & $\mathbf{\square}$ & $\mathbf{\square}$ & $\square$ & $\square$ \\
F.2.1.1 & $\mathbf{\square}$ & $\mathbf{\square}$ & $\square$ & $\square$ \\
G.2.2.1 & $\mathbf{\square}$ & $\mathbf{\square}$ & $\square$ & $\square$ \\
\hline
\end{tabular}

in cases of F.2.1.1 and G.2.2.1. This makes this option less practical for leeward rooms with $\Theta=90^{\circ}$. Moreover, in case F.2.1.1, the diagram presents the highest level of $\mathrm{ACH}$ of $29.1 \mathrm{~h}^{-1}$ with $\Theta=0^{\circ}$ for Room 1 . Despite the increase in the opening size of the façade to $0.5 \mathrm{~h}$, the $\mathrm{ACH}$ was reduced by $30 \%$ in the leeward Room 2 compared with D.1.1.1. Interestingly, this decrease was recovered for the same room after increasing the size of the inner wall to $0.5 \mathrm{~h}$ to match the façade wall. The ACH value for the windward Room 1 is approximately $28.2 \mathrm{~h}^{-1}$.

From the above observations, it can be concluded from Table 4 that the proposed concept of integrated corridor openings in association with inner wall openings is significantly effective for the room conditions with $\Theta=0^{\circ}$, particularly with windward rooms. Large façade openings of $0.5 \mathrm{~h}$ or more with single-sided ventilation are the best option for leeward rooms when $\Theta=90^{\circ}$.

3.4. Comparison of Different Opening Scenarios. As planning and operation guidance, Table 5 outlines the ranking of the optimum conditions with respect to the various analyzed parameters, namely PMV, air velocity, and $\mathrm{ACH}$. The table is structured to indicate the best three conditions considering each of the three parameters for each of the two rooms by each of the simulated wind directions.

The only case that presents the potential for single-sided ventilation is C.2.0.0 for leeward rooms with $\Theta=90^{\circ}$. Apart from the $\mathrm{ACH}$, this case has no potential as a first option for any other parameter. It reappears as a third option for 
TABLE 5: Ranking of optimum conditions with respect to certain comfort parameters.

\begin{tabular}{ccccccccccccc}
\hline & \multicolumn{3}{c}{ Room $1, \Theta=0^{\circ}$} & \multicolumn{3}{c}{ Room $2, \Theta=0^{\circ}$} & \multicolumn{3}{c}{ Room 1, $\Theta=90^{\circ}$} & \multicolumn{3}{c}{ Room 2, $\Theta=90^{\circ}$} \\
& PMV & Velocity & ACH & PMV & Velocity & ACH & PMV & Velocity & ACH & PMV & Velocity & ACH \\
\hline \multirow{2}{*}{1} & F.2.1.1 & F.2.1.1 & F.2.1.1 & E.1.2.1 & E.1.2.1 & D.1.1.1 & G.2.2.1 & G.2.2.1 & C.2.0.0 & E.1.2.1 & D.1.1.1 & C.2.0.0 \\
& 0.02 & 0.86 & 29.10 & 0.58 & 0.20 & 9.04 & 0.73 & 0.11 & 4.00 & 0.72 & 0.11 & 4.03 \\
\hline \multirow{2}{*}{2} & G.2.2.1 & G.2.2.1 & G.2.2.1 & D.1.1.1 & D.1.1.1 & G.2.2.1 & E.1.2.1 & D.1.1.1 & D.1.1.1 & G.2.2.1 & G.2.2.1 & A.1.1.0 \\
& -0.26 & 1.64 & 28.20 & 0.17 & 0.17 & 8.98 & 0.75 & 0.11 & 2.95 & 0.73 & 0.11 & 1.48 \\
\hline \multirow{2}{*}{3} & E.1.2.1 & E.1.2.1 & E.1.2.1 & C.2.0.0 & C.2.0.0 & E.1.2.1 & D.1.1.1 & E.1.2.1 & A.1.1.0 & D.1.1.1 & E.1.2.1 & D.1.1.1.1 \\
& 0.51 & 0.25 & 22.42 & 0.74 & 0.12 & 7.42 & 0.76 & 0.10 & 1.48 & 0.75 & 0.11 & 1.47 \\
\hline
\end{tabular}

the PMV and velocity for the leeward Room 2 for $\Theta=90^{\circ}$. While case G.2.2.1 presents a higher value for velocity $(1.64 \mathrm{~m} / \mathrm{s})$ which helped reach a PMV of -0.26 , it remains less favorable compared with F.2.1.1 for Room 1 in the windward condition, which presents a moderate air velocity $(0.86 \mathrm{~m} / \mathrm{s})$ and a neutral PMV condition. This is mainly due to the uncomfortable impact of the increased air velocity beyond $1.2 \mathrm{~m} / \mathrm{s}$, causing a draft sensation and flying papers.

The diagrams in Figure 10 compare the age of air results across different simulation models with respect to the two wind directions. Conventional solutions, such as A.1.1.0, B1.1.0, and C.2.0.0, present nearly stagnant conditions. However, C.2.0.0 suggests an improvement in $\Theta=90^{\circ}$. It is clear that the configurations of the cases where the age of air is greater than $500 \mathrm{~s}$ should be avoided, such as A.1.1.0, B1.1.0, and C.2.0.0 with $\Theta=0^{\circ}$ and A.1.1.0, B1.1.0, and E.1.2.1 with $\Theta=90^{\circ}$. In the rest of the cases, the leeward space when $\Theta=0^{\circ}$ is in a better condition and lies in the range of $350-450 \mathrm{~s}$ owing to the airflow induced by the negative pressure in the wake zone and the air movement along the sides of the building. In the same cases, the windward rooms present an age of air in the range of 60-80 s, which indicates a high level of air quality. Moreover, for $\Theta=90^{\circ}$, both rooms present identical and certainly acceptable conditions in the cases C.2.0.0, D.1.1.1, F.2.1.1, and G.2.1.1, where the age of air is approximately $200 \mathrm{~s}$.

Thus, considering Table 5 and the results shown in Figure 10, it is useful to mention that providing openings in the corridor wall as well as the building sides to allow using the corridors an air channel helps improve the passive utilization of local wind energy. The difference between the conventional condition of B.1.0.0 and the condition of G.2.1.1 indicates that with the same wind direction, essential changes in the natural ventilation performance can be achieved. Owing to the complexity of the issue, it is notable that each orientation to the wind direction with respect to building geometry should be treated differently. Each scenario delivers different results that affect certain comfort parameters. Therefore, dynamic window-opening scenarios in a building with the suggested configurations can help improve the performance of the openings to improve the level of hygiene and comfort, particularly, if they are operated and determined dynamically with regard to the wind direction. For example, some scenarios can be utilized for a short period of time (e.g., breaktime) to achieve a high $\mathrm{ACH}$, and then a shift to another one is performed to improve the thermal sensa- tion. Building management systems (BMSs) could be of great assistance if they were attached to control the opening sizes and programmed to coordinate with the local wind conditions to achieve certain comfort levels for a particular period.

\section{Conclusion}

The common approach in classroom buildings with doubleloaded corridors is single-sided ventilation because of the difficulty of providing cross-ventilation where air enters from the windward side and exits from the leeward side. In this regard, this study has examined the potential for improving natural ventilation conditions in classroom buildings considering different window-opening scenarios that include the use of room-adjacent naturally ventilated corridors to enhance conventional single-sided ventilation and provide cross-ventilation. Different opening sizes, wind directions, and room locations were considered. The analysis investigated the potential for improving the thermal sensation, air velocity, and air change rate. The examined alternatives were simulated under hot, humid weather conditions. The results could provide decision support for building designers and operators to decide on the opening scenarios for buildings that present similar characteristics to the generic model used in this study. In these models, in addition to the corridor openings, the façade and inner wall openings could reach a size of 0.5 of the room height.

It was found that no single opening scenario could be applied to all façades at any time. This means that each façade is exposed to certain wind conditions and the openings should be designed and managed dynamically, perhaps with the aid of a BMS, to adapt and thus achieve the best results. With the applied low-tech modifications, remarkable increases in $\mathrm{ACH}$, in some cases up to 14.5 times that of the typical single-sided ventilation case, could be seen. Furthermore, the enhancement of the pressure coefficient distribution over the external and internal façades of the building helped elevate the air velocity between the inlet and outlet openings. This resulted in a substantial improvement in the thermal sensation compared with the typical model. The design of future classroom facilities should go beyond the reliance on active mechanical systems and consider a synergy between low-tech and high-tech solutions to achieve user comfort. Natural ventilation is among the many factors that affect the physiological and psychological well-being of the 


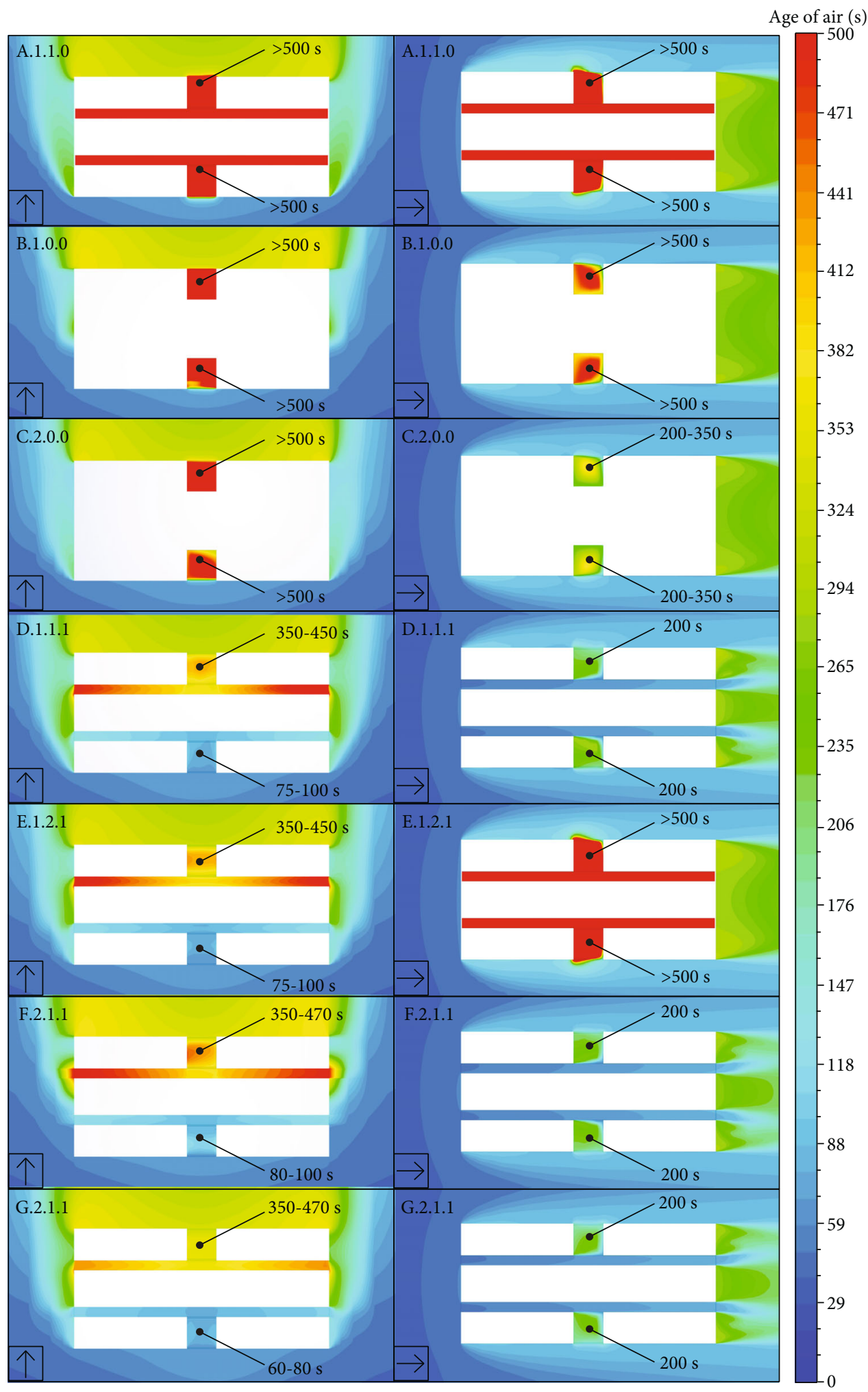

Figure 10: Age of air comparison across different models.

occupants and therefore should be prioritized over other factors. The involvement of wind engineers in early design stages is imperative. In particular, there are serious risks posed by airborne transmitted diseases that require a constant exchange of indoor air. Further research could usefully explore possible solutions for different building heights, configurations, and climate conditions, including different wind directions. Considering the sheltering effect of other structures in further studies is also an essential step in developing better decision support for cross-ventilation. 


\section{Data Availability}

The simulation data used to support the findings of this study are available from the corresponding author upon request.

\section{Conflicts of Interest}

The authors declare that they have no conflicts of interest.

\section{References}

[1] M. Bayoumi, "Energy saving method for improving thermal comfort and air quality in warm humid climates using isothermal high velocity ventilation," Renewable Energy, vol. 114, pp. 502-512, 2017.

[2] D. Rim, S. Schiavon, and W. W. Nazaroff, "Energy and Cost associated with ventilating office buildings in a tropical climate. 1-14," vol. 10, no. 3, Article ID e0122310, 2015.

[3] S. Schiavon and A. K. Melikov, "Energy saving and improved comfort by increased air movement," Energy and Buildings, vol. 40, no. 10, pp. 1954-1960, 2008.

[4] Y. Choi and D. Song, "How to quantify natural ventilation rate of single-sided ventilation with trickle ventilator?," Building and Environment, vol. 181, article 107119, 2020.

[5] H. Fathy, "Natural energy and vernacular architecture: principles and examples with reference to hot arid climates," 1986, http://www.amazon.com/Natural-Energy-VernacularArchitecture-Principles/dp/0226239179.

[6] A. Konya, "Design primer for hot climates," Building Services Engineering Research and Technology, vol. 3, no. 2, p. 90, 1982.

[7] W. Li and Q. Chen, "Design-based natural ventilation cooling potential evaluation for buildings in China," Journal of Building Engineering, vol. 41, article 102345, 2021.

[8] M. Santamouris, A. Synnefa, M. Asssimakopoulos et al., "Experimental investigation of the air flow and indoor carbon dioxide concentration in classrooms with intermittent natural ventilation," Energy and Buildings, vol. 40, no. 10, pp. 18331843, 2008.

[9] M. Santamouris and D. Kolokotsa, "Passive cooling dissipation techniques for buildings and other structures: the state of the art," Energy and Buildings, vol. 57, pp. 74-94, 2013.

[10] G. Santosh, S. Sean, M. Janice, F. Shona, and T. Steve, "Classroom carbon dioxide concentration, school attendance, and educational attainment," Journal of School Health, vol. 84, no. 9, pp. 569-574, 2014.

[11] K. Al-Rashidi, D. Loveday, and N. Al-Mutawa, "Impact of ventilation modes on carbon dioxide concentration levels in Kuwait classrooms," Energy and Buildings, vol. 47, pp. 540549, 2012.

[12] D. Aviv, K. Wee Chen, E. Teitelbaum et al., “A fresh (air) look at ventilation for COVID-19: estimating the global energy savings potential of coupling natural ventilation with novel radiant cooling strategies," Applied Energy, vol. 292, article 116848, 2021.

[13] H. E. Feustel and C. Stetiu, "Hydronic radiant cooling - preliminary assessment," Energy and Buildings, vol. 22, no. 3, pp. 193-205, 1995.

[14] N. Ma, D. Aviv, H. Guo, and W. W. Braham, "Measuring the right factors: a review of variables and models for thermal comfort and indoor air quality," Renewable and Sustainable Energy Reviews, vol. 135, article 110436, 2021.
[15] C. Stetiu, "Energy and peak power savings potential of radiant cooling systems in US commercial buildings," Energy and Buildings, vol. 30, no. 2, pp. 127-138, 1999.

[16] H. Zhao and F. Magoulès, "A review on the prediction of building energy consumption," Renewable and Sustainable Energy Reviews, vol. 16, no. 6, pp. 3586-3592, 2012.

[17] D. U. Hindrichs and K. Daniels, "Plusminus $20^{\circ} / 40^{\circ}$ latitude : sustainable building design in tropical and subtropical regions," in Stuttgart, Edition A. Menges, London, 2007.

[18] C. Ghiaus and F. Allard, "Natural ventilation in the urban environment : assessment and design," 2005, https://books .google.com.sa/books?id=NJo186jmaK0C\&lr=\&source=gbs_ navlinks_s.

[19] B. Givoni, "Passive and low energy cooling of buildings," 1994, https://books.google.com.sa/books?id=rJsVoRw1geoC\&lr= \&source=gbs_navlinks_s.

[20] N. Khan, Y. Su, and S. B. Riffat, "A review on wind driven ventilation techniques," Energy and Buildings, vol. 40, no. 8, pp. 1586-1604, 2008.

[21] C. F. Gao and W. L. Lee, "Evaluating the influence of openings configuration on natural ventilation performance of residential units in Hong Kong," Building and Environment, vol. 46, no. 4, pp. 961-969, 2011.

[22] P. Karava, T. Stathopoulos, and A. K. Athienitis, "Windinduced natural ventilation analysis," Solar Energy, vol. 81, no. 1, pp. 20-30, 2007.

[23] N. Lechner, "Heating, cooling, lighting: sustainable design methods for architects," 2014, https://books.google.com/ books?hl=en \&lr=\&id=WjetCwAAQBAJ\&oi=fnd\&pg= P R 11 \& o t $s=$ Y N P a E Q I M 24 \& $\mathrm{s}$ i $\mathrm{g}=$ HpVcEH3GpHX1O2aXLUeukaZpcmo.

[24] C. M. Mak, J. L. Niu, C. T. Lee, and K. F. Chan, "A numerical simulation of wing walls using computational fluid dynamics," Energy and Buildings, vol. 39, no. 9, pp. 995-1002, 2007.

[25] E. Prianto and P. Depecker, "Characteristic of airflow as the effect of balcony, opening design and internal division on indoor velocity: a case study of traditional dwelling in urban living quarter in tropical humid region," Energy and Buildings, vol. 34, no. 4, pp. 401-409, 2002.

[26] C. Allocca, Q. Chen, and L. R. Glicksman, "Design analysis of single-sided natural ventilation," Energy and Buildings, vol. 35, no. 8, pp. 785-795, 2003.

[27] S.-J. Cao and C. Ren, "Ventilation control strategy using low-dimensional linear ventilation models and artificial neural network," Building and Environment, vol. 144, pp. 316333, 2018.

[28] S. J. Cao, "Challenges of using CFD simulation for the design and online control of ventilation systems," Indoor and Built Environment, vol. 28, no. 1, pp. 3-6, 2019.

[29] W. Liu, H. Huangfu, J. Xiong, and Q. Deng, "Feedback effect of human physical and psychological adaption on time period of thermal adaption in naturally ventilated building," Building and Environment, vol. 76, pp. 1-9, 2014.

[30] H. Wang, B. W. Olesen, and O. B. Kazanci, "Using thermostats for indoor climate control in offices: the effect on thermal comfort and heating/cooling energy use," Energy and Buildings, vol. 188-189, pp. 71-83, 2019.

[31] A. Aflaki, K. Hirbodi, N. Mahyuddin, M. Yaghoubi, and M. Esfandiari, "Improving the air change rate in high-rise buildings through a transom ventilation panel: a case study," Building and Environment, vol. 147, pp. 35-49, 2019. 
[32] Y. Arinami, S. Akabayashi, Y. Tominaga, and J. Sakaguchi, "Performance evaluation of single-sided natural ventilation for generic building using large-eddy simulations: effect of guide vanes and adjacent obstacles," Building and Environment, vol. 154, pp. 68-80, 2019.

[33] H. Wang and Q. Chen, "Modeling of the impact of different window types on single-sided natural ventilation," Energy Procedia, vol. 78, pp. 1549-1555, 2015.

[34] X. Y. Ma, Y. Peng, F. Y. Zhao, C. W. Liu, and S. J. Mei, "Full numerical investigations on the wind driven natural ventilation: cross ventilation and single-sided ventilation," Procedia Engineering, vol. 205, pp. 3797-3803, 2017.

[35] J. Wang, T. Zhang, S. Wang, and F. Battaglia, "Numerical investigation of single-sided natural ventilation driven by buoyancy and wind through variable window configurations," Energy and Buildings, vol. 168, pp. 147-164, 2018.

[36] C. Heracleous and A. Michael, "Experimental assessment of the impact of natural ventilation on indoor air quality and thermal comfort conditions of educational buildings in the Eastern Mediterranean region during the heating period," Journal of Building Engineering, vol. 26, article 100917, 2019.

[37] H. Montazeri and B. Blocken, "CFD simulation of windinduced pressure coefficients on buildings with and without balconies: validation and sensitivity analysis," Building and Environment, vol. 60, pp. 137-149, 2013.

[38] Y. Tamura and R. Yoshie, Advanced Environmental Wind Engineering, Springer, 2016.

[39] J. Von Grabe, P. Svoboda, and A. Bäumler, "Window ventilation efficiency in the case of buoyancy ventilation," Energy and Buildings, vol. 72, pp. 203-211, 2014.

[40] P. J. Richards and S. E. Norris, "Appropriate boundary conditions for computational wind engineering models revisited," Journal of Wind Engineering and Industrial Aerodynamics, vol. 99, no. 4, pp. 257-266, 2011.

[41] M. M. Eftekhari, L. D. Marjanovic, and D. J. Pinnock, "Air flow distribution in and around a single-sided naturally ventilated room," Building and Environment, vol. 38, no. 3, pp. 389397, 2003.

[42] T. Catalina, J. Virgone, and F. Kuznik, "Evaluation of thermal comfort using combined CFD and experimentation study in a test room equipped with a cooling ceiling," Building and Environment, vol. 44, no. 8, pp. 1740-1750, 2009.

[43] J. Franke, A. Hellsten, H. Schlünzen, and B. Carissimo, "Best practice guideline for the CFD simulation of flows in the urban environment," COST action (Vol. 44), 2007, http://cat.inist.fr/ ?aModele $=$ afficheN\&cpsidt $=23892111 \% 5$ Cnhttp: $/ /$ scholar .google.com/scholar?hl=en\&btnG=Search\&q=intitle:Best +practice+guideline+for+the+CFD+simulation+of +flows + in the+urban+environment $\# 0$.

[44] Y. Tominaga, A. Mochida, R. Yoshie et al., "AIJ guidelines for practical applications of CFD to pedestrian wind environment around buildings," Journal of Wind Engineering and Industrial Aerodynamics, vol. 96, no. 10-11, pp. 1749-1761, 2008.

[45] P. A. Mirzaei and J. Carmeliet, "Dynamical computational fluid dynamics modeling of the stochastic wind for application of urban studies," Building and Environment, vol. 70, pp. 161170, 2013.

[46] T. van Hooff, B. Blocken, and Y. Tominaga, "On the accuracy of CFD simulations of cross-ventilation flows for a generic isolated building: comparison of RANS, LES and experiments," Building and Environment, vol. 114, pp. 148-165, 2017.
[47] S. Emeis and M. Turk, "Comparison of logarithmic wind profiles and power law wind profiles and their applicability for offshore wind profiles," in Wind Energy, J. Peinke, P. Schaumann, and S. Barth, Eds., pp. 61-64, Springer, Berlin, Heidelberg, 2007.

[48] G. Hellmann, "Über die Bewegung der Luft in den untersten Schichten der Atmosphäre," Meteorologische Zeitschrift, vol. 34, pp. 273-285, 1916.

[49] P. Lepri, H. Kozmar, Ž. Ve, and B. Grisogono, "A summertime near-ground velocity profile of the Bora wind," Wind and Structures, vol. 19, no. 5, pp. 505-522, 2014.

[50] E. W. Peterson and J. P. Hennessey, "On the use of power laws for estimates of wind power potential," Journal of Applied Meteorology, vol. 17, no. 3, pp. 390-394, 1978.

[51] M. Tahbaz, "The estimation of the wind speed in urban areas height less than 10 metres," International Journal of Ventilation, vol. 8, no. 1, pp. 75-84, 2009.

[52] K. Daniels, “Gebäudetechnologie," in Hochhausatlas, pp. 182201, München, 2002.

[53] Y. Tominaga and B. Blocken, "Wind tunnel analysis of flow and dispersion in cross-ventilated isolated buildings: impact of opening positions," Journal of Wind Engineering and Industrial Aerodynamics, vol. 155, pp. 74-88, 2016.

[54] R. Ramponi, A. Angelotti, and B. Blocken, "Energy saving potential of night ventilation: sensitivity to pressure coefficients for different European climates," Applied Energy, vol. 123, pp. 185-195, 2014.

[55] M. Bayoumi, "Method to integrate radiant cooling with hybrid ventilation to improve energy efficiency and avoid condensation in hot, humid environments," Buildings, vol. 8, no. 5, p. $69,2018$.

[56] J. D. Feng, F. Bauman, and S. Schiavon, "Experimental comparison of zone cooling load between radiant and air systems," Energy and Buildings, vol. 84, pp. 152-159, 2014.

[57] Y. Hirayama and W. Batty, "Dehumidifying chilled radiator system for hot and humid climates," Energy and Buildings, vol. 30, no. 2, pp. 203-210, 1999.

[58] N. Nutprasert and P. Chaiwiwatworakul, "Radiant cooling with dehumidified air ventilation for thermal comfort in buildings in tropical climate," Energy Procedia, vol. 52, pp. 250-259, 2014.

[59] E. Arens, S. Turner, H. Zhang, and G. Paliaga, "Moving air for comfort," ASHRAE Journal, vol. 51, no. 5, pp. 18-29, 2009.

[60] M. Fountain and E. A. Arens, "Air movement and thermal comfort,” ASHRAE Journal, vol. 35, no. 8, pp. 26-30, 1993.

[61] S. H. Ho, L. Rosario, and M. M. Rahman, "Thermal comfort enhancement by using a ceiling fan," Applied Thermal Engineering, vol. 29, no. 8-9, pp. 1648-1656, 2009.

[62] J. Khedari, Comfort, sustainability and energy saving using moving air, Conference Proceeding by ASHRAE, 2008.

[63] J. Khedari, N. Yamtraipat, N. Pratintong, and J. Hirunlabh, "Thailand ventilation comfort chart," Energy and Buildings, vol. 32, no. 3, pp. 245-249, 2000.

[64] Y. Kurazumi, T. Tsuchikawa, J. Ishii, K. Fukagawa, Y. Yamato, and N. Matsubara, "Radiative and convective heat transfer coefficients of the human body in natural convection," Building and Environment, vol. 43, no. 12, pp. 2142-2153, 2008.

[65] A. Lipczynska, S. Schiavon, and L. T. Graham, "Thermal comfort and self-reported productivity in an office with ceiling fans in the tropics," Building and Environment, vol. 135, pp. 202$212,2018$. 
[66] F. Nicol, "Adaptive thermal comfort standards in the hothumid tropics," Energy and Buildings, vol. 36, no. 7, pp. 628637, 2004.

[67] S. Tanabe and K. Kimura, "Thermal comfort requirements under hot and humid conditions," ASHRAE Transactions, vol. 93, pp. 564-577, 1987.

[68] P. O. Fanger, Thermal Comfort: Analysis and Applications in Environmental Engineering, McGraw-Hill, New York, NY, USA, 1972.

[69] M. Griffiths and M. Eftekhari, "Control of $\mathrm{CO}_{2}$ in a naturally ventilated classroom," Energy and Buildings, vol. 40, no. 4, pp. 556-560, 2008.

[70] M. Swami and S. Chandra, "Procedures for Calculating Natural Ventilation Airflow Rates in Buildings," ASHRAE Final Report FSEC-CR-163-86, 1987.

[71] E. Arens, R. Gonzalez, L. Berglund, P. E. McNall, and L. Zeren, "A new bioclimatic chart for passive solar design," Proceedings of the American Section of the Int. Solar Energy Society, University of Massachusetts at Amherst, vol. 5, no. 2, pp. 1202-1206, 1980.

[72] K. Daniels, "Advanced building systems: a technical guide for architects and engineers," 2003, https://books.google.com.sa/ books/about/Advanced_Building_Systems.html?id= xeWpGLytyS0C\&redir_esc=y. 